\title{
Public Reason and Catholic Philosophy in the Post-Thomistic Age
}

\author{
Jovito V. Cariño \\ University of Santo Tomas
}

\section{Abstract}

The term "public reason" came to public attention for the first time when Kant published in 1784 his celebrated essay, What is Enlightenment? In the said piece, Kant described enlightenment as "man's emergence from his self-imposed nonage" and underscored the exercise of public reason as the best demonstration of one's enlightened thinking. ${ }^{1}$ Kant sharply distinguished public reason from private reason. Public reason is characterized by one's ability to think freely whereas private reason is a form of thinking that comes with an external mandate like an office or civic post. For Kant, religion, or for that matter, any form of religious thinking, always involves nonage which, he suggested, must be overcome. My aim in this paper is to rethink Kant's insight on Enlightenment by showing that the exercise of his version of public reason does not exhaust the human person's rational potential and that nonage, that is, dependence on another's guidance, is not an impediment to the flourishing of thought. To make my case, I will rehearse the philosophic practice of Thomas Aquinas to illustrate how advancement in thinking can be achieved even within the confines of religious discourse and the structures of nonage. I argue in this paper that thinking as a public activity always works within the context of normativity, that is, tradition and that intellectual progress can be achieved if the same normative context itself is sustained and constantly re-thought. 
This paper is configured in three parts. In the first part, I shall retrieve Thomas Aquinas' philosophic practice to justify how nonage, that is, thinking within tradition, can itself be a stimulus to improve both the intellectual tradition and the quality of discourse which shapes it. In the second part, I will clarify the idea of "post-Thomistic age" by extending my discussion of Aquinas' philosophic practice but transported to a context which claims to have overcome the kind of intellectual tradition that Aquinas represents. In the third part, I will return to Kant's What is Enlightenment? essay in order to underscore my claim than an enlightened thinking in the mode of Kant's public reason is incompatible with the factual normative situatedness of any thinking process. By way of conclusion, I will sketch a route out of the Kantian distinction between public and private reason by reinforcing my argument concerning the indispensability of normativity in any intellectual enterprise. The rest of the discussion will be guided by the question: Is it possible to conceive of public reason beyond Kant by doing a Thomist philosophy beyond Thomism?

\section{Keywords}

enlightenment, post-Thomistic age, public reason, religion, tradition 


\section{Introduction}

It is not easy to dovetail the idea of "public reason" with the Catholic philosophic tradition given the former's Kantian provenance and the latter's acrimonious history with modernity. With the evolution of Catholic philosophy, however, we are able to see today an improving rapprochement between Catholic intellectuals and the proponents of secular thought. Nothing gives clearer testament of this development than John Paul II's encyclical Fides et Ratio. ${ }^{2}$ In the said encyclical, John Paul II affirms and reframes at the same time the Catholic Church's traditional allegiance to Thomistic philosophy. In a way, we can say that Fides et Ratio is a chronicle of Catholic philosophy's transition to post-Thomistic age, an age where the vitality of Aquinas' philosophic thought is acknowledged simultaneously with the recognition of the need to engage other philosophic views. It goes without saying that besides the task of integrating faith with rational discourse, the challenge faced by Catholic practitioners of philosophy today also includes an updated appropriation of Thomist philosophy against the background of an evershifting intellectual landscape. In the context of this paper, this challenge also suggests the possibility of rethinking both Kant's idea of public reason vis-a-vis the contours of Aquinas' philosophic legacy, hence the title of the paper, Public Reason and Catholic Philosophy in the Post-Thomistic Age. I will argue in this paper that Aquinas' philosophic practice embodies a public reason that can serve as an alternative to the prescription of Kant. Unlike the Kantian model which sought to quarantine religion from rational public discourse, engagement in public reason in Aquinas' fashion pursues public debate without abandoning religion in its core agenda. Religion is integral in Aquinas' intellectual normative context and in his case, reasoning is just as effective when the said intellectual normative context is not set aside. Aquinas is well aware that thinking as a public activity is operative only within the context of normativity or in MacIntyre's term, "tradition." ${ }^{3}$ As the seedbed of intellectual progress, tradition itself needs to be sustained, cultivated, and constantly rethought or it dies a natural death. These important points will be further worked out in the three segments of this paper. In the first part, I shall rehearse Thomas Aquinas' philosophic practice to illus- 
trate how nonage, that is, thinking within tradition, can itself be a stimulus to improve both the intellectual tradition and the quality of discourse from which it is derived. In the second part, I will clarify the idea of "post-Thomistic age" against the background of an age which claims to have overcome the kind of intellectual tradition that Aquinas represents. In the third part, I will return to Kant's What is Enlightenment? to further clarify the incompatibility of Kant's proposal with the factual normative situatedness of any thinking process. By way of conclusion, I will reinforce my argument that neither nonage nor religion is inimical to the advancement of philosophic practice.

\section{Thinking as Conversation:}

\section{Aristotle, Aquinas, and the Medieval Tradition}

A person who can think on his own, unfettered from any tutelage, unhinged from the bondage of intellectual dependence is, in Kant's estimation, a figure of Enlightenment. Thinking, for the enlightened person, is an act of freedom: "This enlightenment requires nothing but freedom-and the most innocent of all that may be called 'freedom': freedom to make public use of one's reason in all matters." Kant's challenge therefore to "dare to know" is not just a call to anyone to turn up his brain cells but to make sure that he does so without any prompting from another. This attitude toward thinking however would have been found "unthinkable" if not outright superfluous by Aquinas and his medieval peers. In medieval context, thinking is never a solitary act but a collective engagement. Students were mentored in apprenticeships. Young professors were honed in disputations. Masters challenged each other via lectures and written treatises. The ancients were commented and debated on. Even the medieval literary genres bear witness to this symposium-approach to thinking. Back then, the mark of scholarship was inked in disputations, commentaries, sentences, letters, and sermons. A scholar was esteemed not so much for his ability to stand above the rest but for his skill to blend his voice with others, in particular, his betters. The said genres were not just documents of conversations; they themselves were conversations awaiting continuity if the reader was willing enough 
to join in. How else should one make sense of Augustine's The Confessions, Boethius' The Consolation of Philosophy, Anselm's Proslogion, Abelard's Sic et Non, Lombard's Sentences, or Thomas Aquinas' Summa Theologica except as conversations in print where the reader is not just a passive eavesdropper but a potential participant in an exchange unfolding before him? Both the Islamic and Jewish scholars also had the habit of bringing in their masters and peers in their works regardless of their agreement or disagreement with them. Whether the material was written in Africa, Cordoba, Persia, Athens, or Paris, the same spirit of dialogue can be found in these philosophic treatises. That the Middle Ages had this peculiar literary and philosophic culture is an important consideration in understanding the importance of nonage in the dynamics of medieval intellectual tradition. Acknowledgment of this fact is necessary if one must appreciate and see in proper context the role of Aristotle in fostering a tradition of thinking descriptive of the intellectual history of the Middle Ages.

Aristotle was a relatively medieval novelty. It was not as if he was completely unknown before the high Middle Ages; his mystique probably came from the fact that, among the ancients, his was the only philosophic system that figured prominently in the Greek, Jewish, and Islamic civilizations and in the thirteenth century, Aristotle was already at the doorstep of the Christian world. Historically, the thirteenth century marked the boundary between the Middle Ages and the proto-modern period or Renaissance. The thirteenth century therefore was a crossroad where a lot of things intersected; the new ones on their way in and the old ones on their way out. Conflict was therefore inevitable and as I will point out in the ensuing parts of this paper, the consequences would be more gravely felt by those on the frontlines of this so-called "clash of civilizations." For the medieval Catholic intellectuals, he was either a breath of fresh air or a portent of an impending doom. Either way, no one among them thought he could be ignored. There is no other way through Aristotle but through Aristotle.

Aquinas was keenly aware of what a conversation with Aristotle would entail. His first encounter with the Greek philosopher started at the University of Naples where the Aristotelian corpus was a staple of the 
curriculum. It was at Naples where he met the two Dominican masters who would later recruit him into the Order of Preachers. The two Dominican brethren, Master Martin and Peter of Ireland, were themselves learned readers of Aristotle. ${ }^{5}$ It is not difficult to imagine how these Dominicans' way of teaching the Stagirite might have been a factor in Aquinas' decision to become a friar preacher like his professors. This radical career detour did not of course sit well with his family who was hoping for the young Aquinas a future far better than becoming a mendicant friar. Hoping his decision could still be undone, he was locked up at the Aquinas' residence at Rocca Secca for almost a year as the family employed various schemes to persuade him to think otherwise. Eventually, his family let him have his way after seeing the futility of their efforts. Upon his release from house arrest, Aquinas was taken in for a discipleship by Albert the Teutonic who himself was a reputed lecturer on Aristotle's Nicomachean Ethics. ${ }^{6}$ The extent of Aquinas' serious interest on Aristotle could also be gleaned from two important opuscula, On Being and Essence $e^{7}$ and The Principles of Nature. ${ }^{8}$ Both pieces were believed to have been written in the middle of the 1250s, that is, after he obtained his master's degree in theology at the University of Paris and before he started writing any of his major works. ${ }^{9}$ Aristotle would have a sustained presence in the rest of Aquinas' oeuvre-in his employment of vocabulary, in the texture of his arguments, in the principles of his discourse. The said treatises serve as veritable testaments to an intellectual kinship with Aristotle that would mark Aquinas' scholarship throughout his life.

The height of this Aristotle-Aquinas colloquium, that is, conversation, would reach its summit in the period 1268-1272 when his Dominican superiors sent him back to the University of Paris to serve as regent master for the second time and to intervene as well in the brewing controversies spawned by the so-called Latin Averroism. ${ }^{10}$ Two important works that would illustrate the extent of Aquinas' involvement in these controversies were the opuscula On the Uniqueness of Intellect against Averroists ${ }^{11}$ and On the Eternity of the World. ${ }^{12}$ Leading the names of the masters from the Faculty of Arts who likewise figured in this high-profile intellectual conflict were Siger of Brabant and Boethius of Dacia. ${ }^{13}$ As the phrase itself suggests, Latin 
Averroism represents a brand of scholarship which drew from the influence of Aristotelian commentator, Averroes. A native of Cordoba in Spain, Averroes, whose original name is Abu'l Walid Muhammad ibn Ahmad ibn Rushd, was a judge by profession and a fierce advocate of a fusion between Islamic religion and Aristotelian philosophy. ${ }^{14}$ His position was directly opposed to those who insisted on the polarity between religion and philosophy like the Islamic theologian al- Ghazali. The disparity between the two thinkers was such that in response to al-Ghazali's Incoherence of Philosophers (Tahafut al-Falasifah) where the latter demonstrated the inherent inferiority of rational speculation in resolving matters of faith, Averroes came up with his own Incoherence of the Incoherence (Tahafut al-Tahafut) in an obvious attempt to rebuke al-Ghazali's dismissive misreading of Aristotle and two other dominant Islamic Aristotelian interpreters, al-Farabi Abu Nasr and Ibn Sina. ${ }^{15}$ Averroes believed that reason and faith, philosophy and theology were complementary systems and that one should see the tension between the two as one of historical contingency. In an important remark, Averroes explained:

Therefore the learned who were instructing the people in Alexandria became Muhammedans when Islam reached them, and the learned in the Roman Empire became Christians when the religion of Jesus was introduced there. And nobody doubts that among the Israelites there were many learned men, and this is apparent from the books which are found amongst the Israelites and which are attributed to Solomon. And never has wisdom ceased among the inspired, i.e., the prophets, and therefore it is the truest of all sayings that every prophet is a sage, but not every sage a prophet; the learned, however, are those of whom it is said that they are the heirs of the prophets. ${ }^{16}$

Averroes was known as "the Commentator" in recognition of his dedication and substantial contribution to the furtherance of Aristotle's intellectual legacy. His scholarly output amounted to a total of thirty-eight commentaries on most known treatises of Aristotle, with roughly two or three commentaries per opus. ${ }^{17}$ Aquinas himself acknowledged Averroes as "the Commentator" 18 a number of times as one would see in de Veritate $10.8^{19}$ or 
Summa Theologica $76.1^{20}$ or De ente et essentia $5 .{ }^{21}$ Such deference however would turn to outright rebuke, when, at the height of the said intellectual disputes, Aquinas derided the esteemed Commentator as, in fact, "the perverter of Peripatetic philosophy." 22

Latin Averroism represented a heterodox strand of the Western appropriation of Aristotle in the thirteenth century, specifically at the University of Paris. On account of the widespread interest on Aristotle's corpus made possible by the increasing availability of translations in Latin from Greek and Arabic, the ecclesiastic authorities of Paris instituted a series of restrictive measures to ensure that the Catholic culture of the Parisian academe was insulated from Aristotle's pagan thought and the influence of his Islamic interpreters. These measures ranged from synodal decree to a censure of a papal legate to a papal letter all aiming at keeping Aristotle at bay. Towards the middle of the thirteenth century however, the censure was relaxed to a certain degree when a letter from Pope Gregory, issued on May 10, 1231, implicitly allowed the masters at the Faculty of Arts to teach selected works of Aristotle free from the threat of excommunication. ${ }^{23}$ By the 1250 s, in stark contrast to the early decades of the $13^{\text {th }}$ century, the University of Paris had adopted a completely Aristotelian curriculum. Within that period, besides the lifting of the prohibition, additional Aristotelian texts, not to mention commentaries and translated versions, were also made more accessible to scholars and enthusiasts alike. Whereas previously, only Posterior Analytics and Ethics were given imprimatur from the 1240s onwards, Aristotelian materials like Metaphysics, De Anima, and other texts on natural science had likewise been delisted from the index of prohibited books. The accessibility of these additional texts provided the academics of Paris new incentives to explore and experiment with the new approaches to science and rational thinking. This was the incipient stage of liberal education medieval-style. The masters at the Faculty of Theology however were rather skeptical about this trend. Consequently, the pockets of tension were further heightened, straining the relations not just between theologians and philosophers but more so, between faith and reason themselves. ${ }^{24}$ This is the context against which one can size up the pivotal role of Siger of Brabant and Boethius of 
Dacia and their head-on confrontation with Aquinas on two pressing philosophic issues: the unicity of the intellect and the eternity of the world. To get a better grasp of Aquinas' intervention on these issues, a brief review of the aforementioned debates is in order.

\section{On the unicity of the intellect}

At the heart of the issue concerning the unicity of the intellect was the question whether or not there was only active intellect. The active or agent intellect refers to the faculty principally responsible for acquiring knowledge. Medieval opinions were torn between positing the existence of the active intelligence outside the human mind and the affirmation of its operation solely within the sphere of human cognition. Some commentaries went as far as identifying the active intellect with God. The resolution of this question was crucial in the interest of the Catholic faith for to think that there was only one active intellect the way Siger of Brabant would have his readers believe, was to seriously undermine Catholic core tenets concerning the origin of ideas, the integrity of the human person, and the formal union between body and soul. ${ }^{25}$ The intense intellectual debates on this issue among the Parisian academics stemmed from a claim made by Aristotle in De Anima III.5. In his account, Aristotle claimed that active intellect is "superior to the passive factor, the originating force to the matter which it forms." He likewise described it as "immortal and eternal."26 What drew the attention of later scholars, in particular the Islamic commentators, was not so much the allusion itself to the active intellect but its surprising appearance at that particular juncture of Aristotle's discourse. He began his discussion in Book I by problematizing the relation between body and soul. ${ }^{27}$ In Book II, he attempted to formulate a working definition of the soul. ${ }^{28}$ In the initial paragraphs of Book III, Aristotle continued to explore sensation as well as the soul-body interaction until that paragraph where he suggested the distinctive nature of active intellect. The shift from the level of biological and material to something that he said was "immortal and eternal" was so drastic it could not but call the attention of later commentators. Reminiscent of Neoplatonic cosmology, Alfarabi considered Aristotle's active intellect as 
the tenth intelligence from which all material things emanated. As a form of intelligence, the tenth itself emanated from the ninth which governed the lunar sphere. Despite being the last in the chain of intelligences, Alfarabi thought that the active intellect occupied a legitimate place in the celestial domain. ${ }^{29}$ Avicenna for his part went beyond Alfarabi by considering the active intellect "to be the cause of the matter as well as the forms of the sublunar world, and to be the cause of the four elements as well as the forms of more complex beings." ${ }^{30}$ On top of this, he also attributed to the active intellect the origin of "the first principles of thought, which are propositions; with abstract human concepts; and with certain other propositions." ${ }^{1}$ Among the medieval Islamic thinkers, none however dealt with the topic of the active intellect more extensively than Averroes as shown by his seven commentaries dealing with the subject matter. Three of the said commentaries dealt with Aristotle's De Anima. ${ }^{32}$ Averroes' controversial position on the active intellect vis-a-vis material intellect could be found in The Long Commentary on De Anima where he was said to have asserted, against the interpretation of other Aristotelian commentators like Alexander of Aphrodisias, Themistius, and Ibn Bajja, in fact, against his own earlier interpretation, that human beings do not possess individual material intellect. ${ }^{33}$ During the thirteenth century, the same opinion would be mistakenly brandished by Siger of Brabant as Aristotle's orthodox opinion on the strength of Averroes' own testimony. ${ }^{34}$ In his contentious Quaestiones in tertium de anima, Siger asserted that the active intellect has no part in the human substantial form and functions only as the cause of human cognition. ${ }^{35}$ This doctrine was also known as monopsychism and was one of the central themes of the medieval Averroist controversy. ${ }^{36}$ For the theologians, Siger of Brabant's position was highly contentious due to its bias against the fundamental principles of the Catholic faith. As early as the 1250s, key intellectual figures of the time like Albert the Great and Bonaventure, by appealing to Averroes' own authority, had already dismissed the Averroist position that Siger adopted. ${ }^{37}$ For his part, Aquinas rebuked Siger of Brabant for a blatant misreading of Aristotle's key philosophic insights. In a polemical treatise entitled De unitate intellectus contra Averroistas, Aquinas publicly called out both Averroes' and Siger of 
Brabant's intellectual gaffe and refuted their claims point by point. ${ }^{38}$ The work was published in 1270 and, though rather short by the standards of Thomistic literature, was doubtless an important material. One may read the said piece as an extension of the same arguments affirming the integrity of the human person clearly stipulated in his other earlier and larger works such as Book II of his Commentary on Peter Lombard's Sentences (1255), Summa Contra Gentiles (1259-1261), Commentary on Aristotle's De Anima (1265-1268) and Summa Theologica, which at the height of the Averroist debates, was yet to be completed. By providing an exegesis of Aristotle's text, Aquinas was able to untangle both Averroes' and Siger's erroneous claims. In his arguments, Aquinas carefully demonstrated how the intellect may be seen as separate on account of its non-dependence on any corporeal organ and at the same time not as a totally separate substance isolated on its own. Aquinas explained: "The human soul exists in its own right and is to a degree united with a matter that does not wholly capture it-this form is greater in dignity than to be a capacity for matter. Nothing prevents its having some operation or power to which matter does not attain." ${ }^{39}$ Aquinas' intervention was by no means an arbitrary rebuttal of the opposite arguments. He knew he had the backing of generations of his fellow Aristotelian interlocutors such as the Greek Themistius, Theophrastus, and Alexander of Aphrodisias, and the Arabic Avicenna and Algazel. All these thinkers were rejected by Averroes and Siger, paying no heed to their common claim that the intellect was a potency of the soul and not a separate substance. Aquinas chided Siger and his fellow Averroists for preferring "to err with Averroes" than "to think correctly with other Peripatetics." ${ }^{40}$ At the latter part of the De unitate intellectus, as he customarily did in his other writings, Aquinas would echo Aristotle to underscore the uniqueness of each individual person against the Averroists' mistaken notion: "A thing is one in the way it is a being, as is said in Book Four of the Metaphysics; therefore, for the soul to be is to be in the body as its form, nor is it prior to body, nonetheless it remains in existence after the body is destroyed: thus each soul remains in its unity and consequently many souls in their manyness." ${ }^{41}$ Like a true master of disputation, hence, an advocate of public reason, Aquinas concluded his piece by directly 
addressing Siger and his cohorts, to come out in the open and publicly engage him should they find his arguments wanting. In a rather emphatic and emotional tone, Aquinas issued this challenge:

If anyone glorying in the name of false science wishes to say anything in reply to what we have written, let him not speak in corners nor to boys who cannot judge of such arduous matters, but reply to this in writing, if he dares. He will find that not only I, who am the least of men, but many others zealous for the truth, will resist his error and correct his ignorance. ${ }^{42}$

Aquinas had always been open about his sentiments for Aristotle and his reverence for Averroes but he was not one who would buy an argument merely because it carried their names. His calling out of Siger of Brabant was yet another manifestation of such partiality towards inquiry and his commitment to a discursive pursuit of truth. As it turned out, what befell Siger of Brabant was not so much his erroneous reading of Aristotle but his blind allegiance to Averroes notwithstanding his gall to brandish as the final word what was in fact a patent mistake. This was not the only time that Aquinas would find himself at the center of a high-profile academic maelstrom.

\section{On the eternity of the world}

Another thorny question on which Aquinas felt compelled to intervene was the issue concerning the eternity of the world. The tenuous contention ascribing eternity to the world did not actually originate from Aristotle. It dates back, said Aristotle in Physics 8.1, to Plato whom he singled out as the lone ancient thinker who thought of time as created while subscribing to the possibility that both time and motion may exist eternally. In his account, Aristotle explained:

Further, how can there be any 'before' and 'after' without the existence of time? Or how can there be any time without the existence of motion? If, then, time is the number of motion or itself a kind of motion, it follows that, if there is always time, motion must also be eternal. But so far as time is concerned we see that all with one exception are in agreement in saying that it is uncreated: in fact, it is just this that enables Democritus to show that all things cannot have had a becoming: for time, he says, is uncreated. Plato 
alone asserts the creation of time, saying that it had a becoming together with the universe, the universe according to him having had a becoming. Now since time cannot exist and is unthinkable apart from the moment, and the moment a kind of middle-point, uniting as it does in itself both a beginning and an end, a beginning of future time and an end of past time, it follows that there must always be time: for the extremity of the last period of time that we take must be found in some moment, since time contains no point of contact for us except the moment. Therefore, since the moment is both a beginning and an end, there must always be time on both sides of it. But if this is true of time, it is evident that it must also be true of motion, time being a kind of affection of motion. ${ }^{43}$

Aristotle must have had in mind Plato's account in Timaeus which featured the latter's speculative narrative of the beginning of time and his description of it as the moving image of eternity. ${ }^{44}$ In late antiquity however, what was formerly a purely cosmological question acquired a more theological tone. From the fourth century onwards, time was equated with motion, that is, with an episode bound by a beginning and an end. Medieval theorists distinguished time from aevum or perpetuity which might have a beginning but has no end and aeternitas or eternity which neither has beginning or end. For the Judeo-Christian tradition, following the testimony of the first chapter of the book of Genesis, the universe had a beginning. Augustine further refined this in The City of God ${ }^{45}$ as well as in his Confessions ${ }^{46}$ where he maintained that time and the world were created by God simultaneously and that neither preceded the other in existence. Against Augustine however, Boethius would claim that while "God indeed is eternal," "the world" nonetheless is "everlasting." In Book V of Consolation of Philosophy, Boethius posited the possibility of the present, that is, time coinciding in the eternity of God's mind, hence, suggesting the apparent overlap between two spheres commonly perceived as contradictories if not mutually exclusive. ${ }^{47}$ This seeming tension between Augustine and Boethius would have a significant bearing on the shape of philosophic and theological debates among the academics of the thirteenth century. As early as 1215, the Fourth Lateran Council had decreed creation in time as an article of faith..$^{48}$ This was further bolstered by the doctrinal inputs by the acknowledged official theo- 
logical sourcebook of the day, Peter Lombard's Sentences which dismissed either theories of Plato or Aristotle as incompatible with Christian faith. There was, he said, a huge distinction between creator and maker or creation and making. A creator makes possible the existence of something from nothing whereas a maker produces something out of a pre-existing entity. ${ }^{49}$ Against Plato, he asserted that creation is distinguished from making since the former involves a radical transition from non-existence to existence whereas the latter merely involves transformation of a thing into something else. Against Aristotle, he maintained invoking Bede that the creation of the world marked the beginning of time hence the world itself is subsumed within the temporal domain. ${ }^{50}$ The Faculty of Theology at the University of Paris, in other words, had very serious reasons why it had to proscribe the study of any of Aristotle's newly translated texts within its hallowed walls. It goes without saying that, among Aristotle's other philosophic concepts, his theory of the eternity of the world gravely undermined the integrity of the doctrine of creation which was at the heart of fundamental Catholic teaching. By the time Aquinas returned to Paris in 1269 , the intensity of the conflict on this raging cosmo-theological question had climbed up to a new high. ${ }^{51}$ One side, counting the likes of Bonaventure, Matthew of Aquasparta, and Henry of Ghent as its advocates, thought that the world had a definite beginning. The other side, which upheld the eternity of the world, included the likes of Boethius of Dacia, William of Ockham, Giles of Rome, and Thomas Aquinas. ${ }^{52}$ If Aquinas therefore was identified on the same side with Boethius of Dacia in this matter, in what way can one consider his opinion an alternative to the perspective represented by the latter? To capture the full import of Aquinas' participation in this debate, one needs to return to the context that gave rise to this thorny and highly divisive intellectual skirmish. The material that could serve as reference to this would be On the Errors of the Philosophers by Giles of Rome. ${ }^{53}$ In the said treatise, Giles of Rome, an Augustinian monk and a student of Aquinas, identified and enumerated what he thought were erroneous conclusions of Aristotle appropriated by his Islamic commentators and their Parisian interlocutors, the so-called Averroists. Giles' work was important as it served as the basis of the 1277 
condemnation issued by Bishop Stephen Tempier, the Bishop of Paris, of the 220 propositions found in the writings of various intellectuals at that time. Seven years earlier, on December 6, 1270, the same Bishop Tempier had already condemned 13 articles deemed injurious to Catholic faith. ${ }^{54}$ Once again, one could only make sense of this aggressive doctrinal cleansing against the background of the increasing influence of Aristotle's philosophic and scientific texts across European universities. The opprobrium was so extensive that it did not spare even the likes of Thomas Aquinas nor Giles of Rome whose very work served as the stimulus in carrying out the all-out offensive against heretical opinions. ${ }^{55}$ Aquinas, in his discourse on the eternity of the world, made no attempt to conceal his sympathy with Aristotle as he did on the topic On the Unicity of the Intellect referred to earlier. At first glance, it would appear as if Aquinas was making too large a concession in these debates in favor of Aristotle. Most of his colleagues at the Faculty of Theology, the so-called neo-Augustinians, were cognizant of this and they did not particularly approve these excursions into philosophy by their fellow master. Bonaventure, for example, short of identifying Aquinas by name, called out those theologians who had been guilty of diluting the wine of the Sacred Scriptures by blending it with the wine of secular thought. ${ }^{56}$ That Aquinas upheld Aristotle's opinion on the question of the eternity of the world is a known fact. ${ }^{57}$ That he compromised his creedal commitment in doing so however is a claim that might be way off the mark. Basically, Aquinas' main contention against Boethius of Dacia stemmed from the latter's failure to recognize Christian faith's inherent openness to rational discourse. His remarks therefore were meant to address, not just the explicit cosmological and metaphysical undertones of the matter at hand but also, the question of whether or not theology could constitute itself as a science. ${ }^{58}$ As far as Aquinas was concerned, to posit the probable eternity of the world hardly undermines neither the power of God nor the integrity of Christian faith, saying, "we ought to admit that God could have made something that has always existed, for it would be clearly derogatory to the divine omnipotence, which exceeds every thought and power, to say that we creatures can conceive of something that God is unable to make." ${ }^{59}$ This important remark 
represents a radical departure from Aquinas' own earlier work, the Summa Contra Gentiles, where he showed from three different perspectives-from the standpoint of God, from the point of view of things made, from the point of view of the making of things-the impossibility of maintaining the notion of an eternal world. ${ }^{60}$ The same is found in the disputation De Potentia Dei where Aquinas clearly asserted, "I answer that we must not hesitate to hold that, as the Catholic faith teaches, the world has not always existed." ${ }^{11}$ Most emphatic of all was Aquinas' pronouncement in Summa Theologica where he stipulated in no uncertain terms that:

Nothing except God can be eternal. ... It is not therefore necessary for God to will that the world should always exist; but the world exists forasmuch as God wills it to exist, since the being of the world depends on the will of God, as on its cause. It is not therefore necessary for the world to be always; and hence it cannot be proved by demonstration. ${ }^{62}$

Given the testimony of these texts, is it fair to say then that Aquinas, in $D e$ Aeternitate Mundi, conceded his faith to Aristotle after all? This is indeed a tempting proposition but one that is difficult to sustain without cautiously considering the nuanced complexion of Aquinas' arguments. A careful reading would suggest that Aquinas' acknowledgment of the theoretical, that is, logical possibility of the eternity of the world was part of Aquinas' overall strategy to secure the discursive integrity of Christian faith. As one commentator pointed out: "The controversy was not over the truth of faith that the world was created. It was over the scientific problem of whether this could also be demonstrated - that is to say, between the respective competencies of theology and philosophy" ${ }^{3}$ There seemed to be a growing number of intellectuals, particularly from the Faculty of Arts, who thought that philosophy should enjoy greater autonomy from theology. Siger of Brabant, who figured earlier, and Boethius of Dacia were representatives of this emerging trend. To their minds, faith and reason, theology and philosophy, were domains walled off by their respective boundaries. This was not the same with Aquinas' notion of distinction between faith and reason. Though autonomous in their respective aims and methods, faith and reason for him were not mutually 
exclusive domains. The way Aquinas saw it, "it is impossible that the truth of faith should be opposed to those principles that the human reason knows naturally." ${ }^{64}$ Hence, when Boethius of Dacia put forward a bold claim that neither the world's co-eternity with divine will nor the eternity of the world itself could be demonstrated rationally, Aquinas had to issue a reply arguing the contrary. ${ }^{65}$ His aim was not so much to engage Boethius in a verbal tussle but to secure the credibility of faith from the threat of fideism. The attempt by Aquinas therefore to show that the eternity of the world or its co-eternity with the divine will is rationally tenable was a strong statement that proves rationality is not an impediment to faith and that faith itself is never just a compromise to an intellectual deficit.

What I tried to show in the foregoing is an illustration of the integral role of nonage or thinking with others in the entire intellectual landscape of the Middle Ages, in particular, in the sustained conversation between Aristotle and Aquinas. That Aquinas depended on Aristotle to flesh out his core ideas is an understatement. Contrary to Kant's injunction however, in Aquinas' experience, nonage proved to be an empowering rather than a debilitating means of intellectual growth. As pointed out at the outset, thinking for Aquinas and his medieval counterparts was never just a solitary process. It always was a discursive exercise within the bounds of tradition where participants, both from the past and the present, converged in pursuit of a matter in question. In the medieval intellectual context, every thinking process was set into motion by a question and this question was the animating element which stirred the discussion to its direction. No medieval thinker therefore would have the audacity to think on his own or for himself, conscious as he was of the preeminence of the tradition whose normative context made it necessary that a question be addressed with a concerted response. It was this kind of intellectual culture that Thomas Aquinas demonstrated masterfully in his opus Summa Theologica. Despite the avowed theological aims, the treatise no doubt qualifies as every inch a philosophical work. That it was philosophical was warranted not so much because Aristotle was everywhere in it but because Aquinas attempted, relentlessly and rigorously, to make faith discursive, that is, to make it a subject matter of exchange or nonage. If 
the charge that Aquinas in Summa Theologica merely baptized Aristotle were true ${ }^{66}$ it might also be correct to say that, in doing so, he likewise Hellenized Christianity. The result, as history bears witness, had become beneficial to both traditions of thought. Kant might have missed it but there could be something potentially creative in nonage; yes, even nonage in religious discourse.

\section{Catholic Philosophy in the Post-Thomistic Age}

The challenge hence for any Catholic practitioner of philosophy is how to carry on Aquinas' philosophic practice in an age that has lost sight of any tradition or in a very Kantian sense, that had been detached from the activity of thinking within a tradition. Apparently, the overcoming of nonage that Kant proposed was contingent upon the revocation of adherence to any intellectual norm. Besides Kant, there were also other voices like Descartes, Nietzsche, Russell, Heidegger, Lyotard among others, who consider repudiation of tradition as the necessary condition of maturity in thought. Yet as I tried to demonstrate in the preceding paragraphs, following an important insight from Alasdair MacIntyre, a rational practice unhinged from a particular tradition is virtually next to impossible. There is no way anyone can make a claim for a presuppositionless presupposition. ${ }^{67}$ The term post-Thomistic age is hence a reference to a hermeneutic space which recognizes the imperative to do Catholic philosophy in the fashion of Thomas Aquinas while recognizing the contemporary predilection against a tradition-bound philosophic discourse. Post-Thomism, in other words, is related, albeit remotely, to kindred terms such as Thomism or Neo-Thomism. The latter stands for specific embodiments of philosophic insights of Aquinas whereas the former suggests an intellectual context which Catholic philosophic thought, in dialogue with other philosophic perspectives, may inhabit. In employing this term, I shall adopt three assumptions which I shall develop in the ensuing discussion. These assumptions are as follows: 1) that faith has an important place in public reason; 2) that the relation between faith and metaphysics may not be an impediment in the exercise of such; and 3) that Thomas Aquinas remains the paradigm of contemporary practice of Catholic 
philosophy. These assumptions will be given further elaboration in the paragraphs that follow.

\section{On faith and public reason}

That one has to insist on the place of faith today in the exercise of public reason might seem strange to a scholar a millennium ago who, conversely, considers it an oddity for anyone to argue for the importance of reason in the discussion of matters of faith. This radical reversal of intellectual paradigm, however, is by no means an accident of history but an outcome of major ideological conflicts which eventually led to the wholesale displacement of faith in what is now known as modernity. Quite ironically, this escape from the theological, says Michael Allen Gillespie, has, in fact, theological roots. Gillespie explained:

... while modern metaphysics began by turning away from both the human and the divine toward the natural, it was able to do so only by reinterpreting the human and the divine naturalistically. However, both were thereby incorporated within the naturalistic perspective. In incorporating them in this manner, however, the earlier conflict between the human and the divine was not resolved but concealed within the new metaphysical outlook. $^{68}$

This reverse sublation from supernatural to natural renders the theological inescapable in the reckoning of secular matters just as it makes the inclusion of the secular standpoint an imperative in addressing questions of faith. Instantly, this perspective overcomes the divide between secular civilization and salvation history suggested either by Augustine in favor of the latter or by the likes of Sam Harris, a fierce advocate against religion and theism, in favor of the former. ${ }^{69}$ Augustine represents the belief that everything culminates in and is subsumed under the sacred hence the primacy of the theological. Harris, on the other hand, devalues the holy so as to elevate the human, hence, the reference, secular. ${ }^{70}$ Dichotomy as a cultural problem, in other words, is ever ancient as it is ever new. Aquinas had likewise confronted dichotomies similar to this and in his philosophy offered a way to repair the gaps which divide believing and knowing, matter and form, matter and spirit, heaven 
and earth. Despite what he had achieved, the lure of dichotomy continues to persist until today. This is not to suggest that synthesis is a useless task; it only underscores the fact that it is a historically contingent necessity and, on account of its fragile nature, requires constant re-configuration and re-calibration. Not all dichotomies however are the same. Augustine for example posited a sharp demarcation between the city of man and the city of God to separate the decadent civilization of Rome and its civic religions from the Christian civilization on whose foundation the reign of God shall come. This is different from Harris' dichotomous proposal by which he wished not to delineate Christian civilization from a rival socio-political order but to banish religion, Christianity, and Islam in particular, from humanity itself. In Harris' contention:

Religious faith represents so uncompromising a misuse of the power of our minds that it forms a kind of perverse, cultural singularity-a vanishing point beyond which rational discourse proves impossible. When foisted upon each generation anew, it renders us incapable of realizing just how much of our world has been unnecessarily ceded to a dark and barbarous past. $^{71}$

Harris conflated religion with religious extremism and, like what Rome did during Augustine's time, pinned the blame for societal decay on the very existence of Christian and, by extension in his book, Islamic faith. He cited the episodes of violence, intolerance, and barbarism propagated in the name of religion and used them to argue for its outright banishment from modern human civilization. For him, it was religion that bred these manifestations of human degeneration. Consequently, besides creating a polarity between the religious and the human, Harris likewise insisted on yet another duality, that is, between the past and the present or between the ancient and the modern. ${ }^{72}$ In a contrary fashion, Augustine found Rome in the same predicament and used what he saw to make a case for the city of God on account of Christianity's more superior moral vision. Augustine remarked, "But what kind of gods were these, pray, who declined to live with a people who worshipped them, and whose corrupt life they had done nothing to 
reform?"73 In a contest between a purely civic polity and a Christian society, he picked the side of the latter conscious of the fact that a civilization inclusive of authentic Christian faith is more conducive to the attainment of human flourishing. He called upon the Romans to "[1] ay hold now on the celestial country, which is easily won, and in which you will reign truly and for ever. . . Incomparably more glorious than Rome, is that heavenly city in which for victory you have truth; for dignity, holiness; for peace, felicity; for life, eternity." ${ }^{74}$ Augustine, in other words, resorted to the dichotomy attributed to him as a discursive strategy to illustrate the possible overcoming of the radical contrast between a civilization where God is absent and a civilization founded on God's reign. For Harris, in contrast, it was the futility of such overcoming that he sought to underscore via his vision of human civilization, if indeed a civilization bereft of religion may qualify as human.

Harris' position is representative of the so-called "new atheism," a strand of anti-religious thought which gained traction in the early part of the $21^{\text {st }}$ century through the writings of its leading voices which, besides Sam Harris, included Richard Dawkins, Christopher Hitchens, and Daniel Dennett. ${ }^{75}$ These four thinkers are the main proponents of the updated, re-branded version of atheism which they distinguish from its older forms by accentuating religion's incompatibility with the scientific orientation of the contemporary modern culture. There is of course nothing new to this story. What is probably new is the way this recent strand of atheism capitalizes on science which, for the most part, has gained control of much of our civilization today. Science has become a rival of traditional normative resources like religion from which values, norms, even incentives for human fulfillment are derived. The "new atheism" views religion as science's anti-thesis and aspires to establish a new world order purged of religion's impurities. In explaining its features, the author Stephen LeDrew described "new atheism" as "an extension and manifestation of the modern project of the scientific mastery of the world and the rationalization of society, and its critique is ostensibly only about religion." ${ }^{\prime 6}$ Unlike therefore the Psalmist's fool who thought in his heart there was no God or the existentialist who spurned providence 
weighed down as he was by his existential angst, the new atheist turns to religion as an object of inquiry and rejects it for being unscientific. On this account, new atheism extends and at the same time departs from scientific atheism bannered by Enlightenment thinkers like Diderot and Voltaire and the humanistic atheism of anti-Enlightenment philosophers like Marx and Nietzsche. The former was a rejection of religion as an obstacle to social and scientific progress while the latter was a refusal of the decadent ground of a dysfunctional moral order. Despite their initial popular success however, the said new atheists, or the "brights" as they proclaimed themselves to be, contributed very little to elevate the faith and reason debate. Observers trace the reversal of the once progressive momentum of the so-called "atheist spring" 77 to the conceit, intolerance, and hubris of its high priests besides their shameless dogmatism. In the end, the new atheists' tirades against religion became the very thing that undermined their case. The irony of the situation did not escape the likes of Terry Eagleton who, in his review of God Delusion in the London Review of Books, practically leveled Dawkins' work to smithereens. In his scathing piece, Eagleton described rabid rationalists like Dawkins as "the least well-equipped to understand what they castigate, since they don't believe there is anything there to be understood, or at least anything worth understanding." ${ }^{78}$ Eagleton likewise wrote:

Imagine someone holding forth on biology whose only knowledge of the subject is the Book of British Birds, and you have a rough idea of what it feels like to read Richard Dawkins on theology. . . . What, one wonders, are Dawkins's views on the epistemological differences between Aquinas and Duns Scotus? Has he read Eriugena on subjectivity, Rahner on grace or Moltmann on hope? Has he even heard of them? Or does he imagine like a bumptious young barrister that you can defeat the opposition while being complacently ignorant of its toughest case? ${ }^{79}$

The new atheists' obsession to topple religion led them to a misconception that they could do so without paying attention to the intricacies of theological discourse. It goes without saying that atheism, whether in the form of old or new, could only thrive if it engages the anti-thesis it is seeking to dismiss. As James Wood put it, belief and unbelief are "structur- 
ally related"80 - the possibility of one requires the existence of the other. Any critique, whether for or against faith, presupposes the dialectic configuration of their confrontation. Having seen its intellectual deficit, very few reputable scholars today align themselves with the new atheists' proposal to banish faith or religion completely from rational discourse. The preceding discussion shows precisely why and how this tact cannot flourish. Faith indeed is a distinct domain but it is no doubt a rich moral, cultural, and intellectual norm. If only for this, Aquinas will remain a thinker to contend with. No less than Habermas himself recognizes the extent of his influence when he wrote:

Reading Aquinas' Summa Contra Gentiles, I am struck by the complexity, the sheer degree of differentiations, the gravity, and the stringency of the dialogically constructed argument. I am an admirer of Aquinas. He represents a form of spirit that is able to ground its authenticity from out of its own resources. It is simply a fact that there is no longer this kind of firmament in the morass of contemporary religiosity. In a homogenizing media society, everything loses its gravity, perhaps even institutionalized Christianity itself. ${ }^{81}$

The quote cited above represents the most recent evolution of Habermas' thought concerning religion. What is suggested in this fragment is an apparent recognition on his part of the potency of religion and its singular role in shaping the contemporary ethico-political discourse. The acknowledgment of the enduring relevance of Aquinas' intellectual legacy is also noteworthy. There is nothing gratuitous nor arbitrary in this so-called Habermasian theological turn. ${ }^{82}$ This dramatic shift in his interpretive horizon is in fact an outcome of Habermas' sustained reflection on the role of religion in public life. It is to such theme that I wish to turn in the next segment.

\section{Between faith and metaphysics}

One would recall Habermas in his early work The Theory of Communicative Action described how "the socially integrative and expressive functions that were at first fulfilled by ritual practice pass over to communicative action; the authority of the holy is gradually replaced by the authority of an achieved 
consensus." ${ }^{83}$ Further, he likewise wrote that "[r] eligion serves only to interpret existing ritual practices in concepts of the holy; without a strictly cognitive content, it has not yet taken on the character of a worldview." ${ }^{44}$ Although not directly dismissive, Habermas's tone in this text may be qualified as minimalist in its approach to religion. Religion is not necessarily devalued but the recognition of its worth is constrained by a perspective which tends to confine it to a particular, determinate role and within a specific, restricted context. In this phase of his intellectual itinerary, Habermas' reading of religion remained opaque caught as he was between isolating religion for lack of "cognitive content" and recognizing its potential to ascend to a "worldview." He would however recalibrate his tone in latter works like Moral Consciousness and Communicative Action which detailed the parameters of his proposal for a discourse ethics. In the said work, Habermas suggested that "[o]nly those norms can claim to be valid that meet (or could meet) with the approval of all affected in their capacity as participants in a practical discourse." 85 One may detect two important implications in this recommendation: either Habermas is leaning towards a more hospitable approach to religion which, as a norm, stands a chance of securing legitimacy in the public sphere if it meets the approval of all those involved in practical discourse, or, he is actually raising the bar which would make it impossible for exclusive and conservative norms like religion to secure a public validation. Judging however from the succeeding phase of the evolution of his philosophic thoughts, one may securely infer that Habermas' ties with religion did indeed grow warmer as the book Postmetaphysical Thinking seems to indicate. He wrote and with no small surprise to his readers:

Viewed from without, religion, which has largely been deprived of its worldview functions, is still indispensable in ordinary life for normalizing intercourse with extraordinary. For this reason, even postmetaphysical thinking continues to coexist with religious practice-and not merely in the sense of the contemporaneity of the noncontemporaneous. This ongoing coexistence even throws light on a curious dependence of a philosophy that has forfeited its contact with the extraordinary. Philosophy, even in its postmetaphysical form, will be able neither to replace nor to repress religion as a long as religious language is a bearer of semantic content that is inspiring 
and indispensable, for this content eludes (for the time being?) the explanatory force of philosophic language and continues to resist translation into reasoning discourses. ${ }^{86}$

The text cited above conveys a dramatic shift in both tone and direction of Habermas' perspective on religion. More than mere conciliatory, the text evidently shows a more sober stance of philosophy vis-à-vis religion. It also renders an account of religion's inherent potential in a clearer and more positive light. Attached with this altered perspective however is a new problematic that comes with the dawn of what Habermas describes as "postmetaphysical thinking." Chronologically, postmetaphysical thinking qualifies as the aftermath of metaphysical thinking but in Habermas' description, the sequential conjunction between the two does not appear as neatly as it should. For one, Habermas himself, at least in the essay "Themes in Metaphysical Thinking", is rather ambivalent in saying whether we have really arrived at a juncture where metaphysical thinking has been completely overcome. ${ }^{87}$ In other words, the irreplaceability of religion alluded to by Habermas is not really a cause of relief if it included: a) the continuous identification of faith with metaphysics; and b) as a result of the former, the persistent marginalization of religious language from public discourse. While Habermas therefore seemed ready to concede the possible transition of philosophy from metaphysical to postmetaphysical thinking at some future indefinite point, he appeared unconvinced that a similar development would yet take effect in the domain of faith. However, given the complex dynamics between metaphysics and religion, one must approach this metaphysical imputation to faith, something widely shared by most thinkers of postmodernity, with careful consideration. ${ }^{88}$ There is therefore a need to go beyond perfunctory reading of Nietzsche's death of God or Heidegger's dismissal of onto-theology if the question of religion's complicity with metaphysics must be dealt with squarely. The triumphalistic defense of the perennial validity of metaphysics likewise will no longer do. Currently, there are already attempts to explore the possibility of developing a discourse either on faith or God without acceding to the architectonics of metaphysics. One may locate the 
efforts of Gianni Vattimo ${ }^{89}$ and Richard Kearney ${ }^{90}$ in this campaign together with such authors like Eric E. Hall \& Hartmut von Sass ${ }^{91}$ and Kevin W. Hector. ${ }^{92}$ Adjacent to the Thomistic tradition is Jean-Luc Marion's rendition of a God beyond being which radically uprooted theological discourse from its traditional metaphysical ground..$^{93}$ If one refers to contemporary literature therefore, it is evident that faith remains a potent resource of intellectual discourse. What is sidelined by the postmodern conversations on belief is not so much faith per se but its metaphysical baggage. Given this predilection, a Catholic philosopher may hence find himself hindered from actively engaging in the exercise of public reason considering the Catholic faith's historic entrenchment with its metaphysical heritage. Faced with this quandary, he may then experiment with any of the following possibilities: a) to preserve the foundational character of Catholic metaphysical tradition against the contemporary postmetaphysical temperament; b) to abandon such tradition in keeping with the current persuasion against metaphysics; or c) to be creative in appropriating the Catholic metaphysical tradition while pursuing the requisites of public reason. The first possibility is represented by the figure of a self-styled Thomist who erroneously perceives Aquinas as an architect of a metaphysical system. This is the case of those of unknowingly mistake Aquinas for Francisco Suarez, the modern propagator of Scholasticism who was credited for having transformed metaphysics into a distinct science. The second possibility is represented by the figure of an avant-garde Catholic thinker who reads philosophy in a linear fashion. For him, ideas and concepts are constantly mutating and are prized not so much for their longevity as for their novelty. His philosophic views are contingent upon the trendy and the latest. A philosophic thought, he believes, is as good only as its update like a fashion style or fancy gadget. He categorizes ideas according to the names of those who most recently mouth them. He will take Zizek over Plato anytime simply because Plato is long dead and Zizek isn't. The third possibility is represented by no less than Thomas Aquinas himself. He remains the paradigm of Catholic philosophic practice despite being a professional theologian thanks to his exceptional acumen to make distinctions when resemblance is too close and to harmonize what appears 
to be remotely dichotomous. Aquinas is the embodiment of what Habermas refers to as "the epistemic ability to consider one's own religious convictions relexively from the outside and to connect them with secular views." ${ }^{94} \mathrm{On}$ account of this ability, Aquinas succeeds in utilizing metaphysics without ever confining himself to its rigid structure.

\section{Aquinas as paradigm of Catholic philosophic practice}

The equation between faith and metaphysics is an important issue not just in postmodern philosophic discourse but also in Thomistic scholarship. Aquinas' employment of metaphysics as shown by his indebtedness both to Plato and Aristotle is well documented. ${ }^{95}$ The million-dollar question however is whether Aquinas' recourse to metaphysics qualifies him as a metaphysician. The same question may be asked in another way: As a thinker, does Aquinas' instrumental recourse to metaphysics automatically make his thought metaphysical?

An affirmative answer to this query automatically suggests that anyone who maintains a collection of books is a librarian or any person who can play a guitar is a musician. An approach as simplistic and counterintuitive as these examples suggest certainly will not help in confronting the complexity of the matter. That the question requires a serious and repeated consideration is an understatement. What is at stake after all is not just the reputation of Aquinas as a philosopher but the whole complexion of Catholic philosophic tradition. If Aquinas then is the acknowledged mouthpiece of Catholic philosophy, whatever is said of him resonates as well with what he stands for. In this paper I put forward a claim that the description "metaphysical" in reference to Aquinas' thought is problematic precisely because the perspective on which this claim is based, that is, the perspective which judges the Catholic philosophic tradition as metaphysical, is itself problematic. By making this claim, I am placing myself in a position directly opposed to Heidegger who famously defined metaphysics as onto-theology. ${ }^{96}$ For Heidegger, the character of metaphysics as onto-theology is an outcome of the deity's advent into philosophy. As Heidegger puts it: "Metaphysics is theology, a statement about God, because the deity enters into philosophy." ${ }^{" 7}$ Metaphysics needs 
to be re-thought, says Heidegger, for it is only in such re-thinking that one can trace how Being comes into thought. In response to his self-formulated problem, Heidegger explained that the deity or Being enters thought "in the nature of the ground. ${ }^{" 98}$ One gains access to the deity or Being by conceiving of it as ground; only by recognizing it as such does thinking of beings becomes possible. At this point, one may ask whether this description of metaphysics coincides with Aquinas's own project. Three important questions therefore may be asked related to this matter: first, whether Aquinas considers "Being as ground" as the subject matter of metaphysics?; second, whether Aquinas considers such Being as the "ground of beings?"; and third, whether Aquinas considers Being as an object of thought?

Concerning the first question, Aquinas was rather explicit in the preface of his commentary on Aristotle's Metaphysics that the subject matter of metaphysics was not Being nor any particular being but being in general or ens commune. ${ }^{99}$ Being in general or ens commune is an expression that Aquinas used to refer to the question of existence. When he engages hence in a metaphysical investigation, Aquinas concerns himself not with any existing Thing or things but with the problem of existence itself. Metaphysics is differently known as divine science or theology or first philosophy but this is so, explains Aquinas, only because the problem of existence ultimately has bearing in the study of particular existing things. The lament therefore of Heidegger regarding philosophy's prejudice for the question of beings rather than Being may not apply to Aquinas. His engagement with Aristotle's metaphysics shows how the matter had been anticipated by him long before Heidegger considered it as the ultimate phenomenological problem.

Concerning the second question, Aquinas indeed considered God as the author of creation thus making the suggestion that the latter might be, in a sense, the ground of its being. It is arguable however whether the Being as ground extrapolated by Heidegger is comparable with God as propounded by Aquinas. For one, strictly speaking, God as suggested by Aquinas is not even a being. Strictly speaking, since God is not a being, God does not exist, that is, in the fashion of some existing thing. Aquinas explains that God "does not have a quiddity or essence, because his essence is not other than 
his existence. And from this it follows that he is not in a genus, because everything which is in a genus must have a quiddity which is other than its existence." 100 Aquinas refers to this as his notion of God's simplicity. ${ }^{101}$ That God is simple means God is radically different from any part of creation. In Summa Contra Gentiles, Aquinas went as far as saying that "God is not the being of all things, we can likewise show that He is not the form of any thing." 102 This is Aquinas' way of describing the infinite distance between any created nature and God. In the disputatio De Potentia Dei, in his reply to the ninth objection of Question 3, Article 4, he alludes to how between "God and the creature there cannot be a generic or specific likeness, there can nevertheless be a certain likeness of analogy, as between potentiality and act, substance and accident." ${ }^{103}$ Instead of ground, Aquinas is more inclined to consider God as cause on account of its being existence itself, that is, pure act. ${ }^{104}$ Nothing is ever really sui generis. Such for Aquinas is a logical, ontological, and cosmological abomination. Everyone, everything is a participant in such an existence just as every fish, every coral, every sodium molecule is a participant in the vast ocean. "Every other being," says Aquinas, "is a being by participation." 105

Concerning the third question, it is rather clear for Aquinas that Being, in the sense of deity as conceived by Heidegger, is something that cannot be thought. While Heidegger problematizes the advent of Being to philosophy, quite ironically, for Aquinas and his medieval peers, the main concern was the encroachment of philosophy into the realm of the deity. Aquinas is one with the great minds of medieval thought, from Augustine to Meister Eckhart, in the notion that God is the utterly other of human comprehension. Anselm's description of God in the Proslogion as a being than which nothing greater can be thought is an enunciation of a clever scheme which simultaneously affirms and denies human thought's ability to foray into the realm of the divine. While maintaining a similar apophatic stance, Aquinas' view regarding such ability is comparably more moderate than that of Anselm. He concedes that reason may know God by virtue of his effects but it "cannot reach up to simple form, so as to know 'what it is'; but it can know 'whether it is."” ${ }^{106}$ In preserving God's unknowability, Aquinas effectively sets the limits 
of metaphysics. In doing so, he succeeds in sustaining Aristotle's project of developing a rational and systematic approach to know what lies beyond the world of change while he identifies what cannot be attained by this metaphysical experiment. If metaphysics as understood by Heidegger as the site in which the deity comes to thought, then Aquinas is not the metaphysician that most people thought he was. As pointed out in the preceding part, the grave concern of most medieval thought leaders was not so much the deity's arrival to thinking but the presumption of thinking that it can get near the divine. This was the scandal that Aquinas sought to avoid.

The recognition then of Aquinas as the paradigm of Catholic philosophic thinking stems not just from his ability to secure for Catholic faith a rational demonstration but also from his ingenious way of presenting Catholic faith as an intellectual resource which shaped the content and direction of intellectual debates inside or outside the Catholic circle. Not only did Aquinas participate actively and aggressively in these debates; he in fact personified via his vast corpus of works the gravitas and complexity which attended the fermentation of Catholic philosophic thought during the Middle Ages. Catholic philosophy, in particular, its medieval episode, has been unfairly caricatured in most accounts of the history of philosophy as a flatline owing to its deep entrenchment in metaphysics. Bertrand Russell went as far as describing Catholic philosophy as a terrain within which "intellectual activity was almost non-existent."107 Obviously, Russell did not or had very little appreciation for an intellectual engagement which included and depended on faith. His reading typifies a hermeneutic which grossly ignores the tensions and turns underlying what appears in the surface as a lifeless narrative showcasing a string of theological terms. What it fails to take into account is the fact that Catholic philosophy, far from being a terrain hemmed in by metaphysics, is actually a site in which metaphysics is both sustained and restrained as shown by the literature produced by the leading intellectual figures of the time. Given a close attention to the texts, there is no way anyone can miss their vigorous exchanges all with the intent of outdoing each other in framing better the thorny relationship between faith and metaphysics. This is the kind of dynamics embodied by Thomas 
Aquinas both in his philosophic practice and body of works. Aquinas is a metaphysician in the sense that he was a scholar who endeavored profoundly to examine metaphysics and its bearing on Catholic faith but not in the sense of a dogmatic thinker who confined himself with the strictures of metaphysical thinking. The former evokes the kind of intellectual dexterity which allowed Aquinas to move in and out of both faith and metaphysics so as to simultaneously affirm and challenge their claims. This agonistic approach helped Aquinas to articulate the dynamism between faith and reason which enables them to remain autonomous while remaining in conjunction with one another. Faith and metaphysics are traditions in which Aquinas is competently and equally conversant. His is what may be characterized as a creative fidelity by virtue of his ability to act both as custodian and critic of these two streams of thinking. I suppose this is the kind of epistemic ability which Habermas claimed is necessary for a believer to engage in the exercise of public reason. Tradition, fidelity, creativity-these are the operative terms which can best describe Aquinas' engagement in responding to the critical questions of his day. They also evoke the same attitude that one must imbibe to practice public reason in the post-Thomistic age.

\section{Kant, Public Reason, and Enlightenment}

In the foregoing discussion, I have tried to provide a sketch of Aquinas' philosophic practice of thinking within a specific intellectual normative context or tradition. What this practice amounts to is a sustained conversation among participants who create and re-create a tradition's narrative structure and content. During the medieval ages, this kind of conversation was pursued by Aquinas with his academic peers at the Faculty of Arts along with his Greek and Islamic predecessors. Such exchanges demonstrate the indispensability of critique and tolerance both of which are key dispositions instrumental in preserving the hermeneutic space through which the relentless quest for truth can be carried out. In participating in these exchanges, Aquinas managed to bring Catholic faith and non-Catholic thought at a juncture where their critical interface became possible. The result of these efforts, as some scholars would say, was a Christianized Aristotelian philos- 
ophy which emerged essentially via the grammar of a Hellenized Christian theology. Embedded within Catholic philosophy then is a dynamic intellectual tradition built on the foundation of a constructive dialogue and self-critique. In this context, nonage, frowned upon by Kant in his aforementioned essay, not only may be considered a virtue but more an enabling process to animate the practice of public reason. To do philosophy then in what I described as post-Thomistic age, adherents of a Thomist philosophic practice must imbibe this intellectual orientation as well as the critical competencies required by this enterprise be it in the form of a dialogue on the problem of new atheism or post-metaphysical thinking or the reconfiguration of the problem of metaphysics as illustrated above. It remains to be seen, however, whether the arguments put forward against Kant's dismissal of nonage and his conservative take on the nature and function of public reason can be validated by perspectives drawn from a parallel intellectual normative context. It is for this reason that I now turn to the German intellectual culture that gave rise to the question concerning Enlightenment which in turn paved the way for the celebrated Kantian essay.

It is hard to pin down where exactly the first stirrings of Enlightenment came to be. ${ }^{108}$ What is certain is Enlightenment is a European phenomenon cultivated by the greats of the Dutch, Scottish, English, French, and German intelligentsia. Two major themes characteristic of the aims of Enlightenment are rationalism and emancipation. ${ }^{109} \mathrm{With}$ the former, one can easily identify the likes of Leibniz and Wolff; with the latter can be aligned the French Encyclopaedists led by Diderot and, by virtue of his singular piece on the theme, Immanuel Kant. In the essay, as pointed out earlier, Kant defined in no unclear terms his understanding of enlightenment as freedom from tutelage and rejection of nonage in any form. He likewise singled out religion as inimical to public reason. Kant's answer to the question "What is Enlightenment?" is probably one of the philosophical themes fiercely debated and copiously commented on through the centuries. ${ }^{110}$ That this is so, I suppose, is due not so much to any distinct aspect of his remarks but because Enlightenment itself, the main motif of his address, is a highly contested subject matter. 
It should be pointed out that Kant's essay was but one of the many attempts to answer the same question. In the same year, 1784, two other works dealing with the same topic of Enlightenment were published in Germany: Moses Mendelssohn's On the Question: What is Enlightenment? and Karl Leonhard Reinhold's Thoughts on Enlightenment. A year before that, Johann Karl Mohsen's What Is to Be Done toward the Enlightenment of the Citizenry? came out. ${ }^{111}$ Within the last two decades of the eighteenth century, most leading German intellectuals including the likes of Fichte, Hamann, and Jacobi among others, also took part in grappling with the impact of this cultural ferment which had taken hold of Europe and in the tail end of the eighteenth century had likewise swept Germany. All the aforementioned thinkers, along with their peers, were at the forefront of public debates on the different features of Enlightenment. Each wanted to contribute something to the public understanding of a number of great changes in European culture which the Enlightenment symbolized. Kant's was but one of the many voices in this public exchange. As such, his essay matters not so much due to any distinct insights but due to certain commonalities that his remarks share with other views. Here is a case where the posing of the question exceeds in importance any particular answer. This is not to say that Kant has nothing compelling to offer in his piece. What I simply wish to suggest is that his discussion of the Enlightenment question should be seen as part of an unfolding larger conversation. What counts above all is nothing else but the question, "What is Enlightenment?"

If the Enlightenment question generated such varied reactions from the leading thinkers of the eighteenth century, it was mainly because of its public character. The debates drew their inspiration from the discourses of French intellectuals, also known as the philosophes, ${ }^{112}$ who were looking for a way to re-think citizenship amidst an environment transitioning from the dominion of the ancien regime. ${ }^{113}$ Habermas identified this distinct historical juncture as the period which paved the way for the "genesis" of the public sphere. He describes it thus:

A few years before the French Revolution, the conditions in Prussia looked like a static model of a situation that in France and specially in Great Britain 
had become fluid at the beginning of the century. The inhabited judgments were called "public" in view of a public sphere that without question had counted as a sphere of public authority but was now casting itself loose as a forum in which the private people come together to form a public, readied themselves to compel public authority to legitimate itself before public opinion. The publicum developed into the public, the subjectum into the (reasoning) subject, the receiver of regulations from above into the ruling authorities' adversary. ${ }^{114}$

Kant's predilection then for freedom in the exercise of public reason is informed by his participation in the growing clamor for an expanded role of citizens in the political arena. Mendelssohn's thoughts on the matter are comparatively more conservative given his emphasis on culture, education, language, and the essential destiny of citizens. He has none of Kant's radical proposals, specifically on the matter of promoting Enlightenment as a counter-culture, but his thoughts are considered important since they formed part of the larger intellectual context which shapes Enlightenment discourses. ${ }^{115}$ Almost approximating Mendelssohn's points are those made by Mohsen. ${ }^{116}$ He too believes that the work of Enlightenment can be facilitated by the existing mechanisms of culture and education. These views of course are countered by Kant as shown by his partiality against tutelage. It has likewise been noted that Kant has tremendous reservations against religion on account of the latter's tendency toward absolutism and obscurantism. On this matter however, Kant is rebuffed by Friedrich Heinrich Jacobi who considers religion as indispensable in securing the general welfare of humankind. Without religion, says Jacobi, this can only be effected by an "utmost power" albeit in an "inadequate manner."117 Although in his later work, Religion within the Boundaries of Mere Reason, Kant would expand and further amplify his religious views, he remains uncompromising when it comes to the preeminence of reason when dealing with matters of faith. He claims,

Friends of the human race and of what is holiest to it! Accept what appears to you most worthy of belief after careful and sincere examination, whether facts or rational grounds; only do not dispute that prerogative of reason 
which makes the highest good on earth, the prerogative of being the final touchstone of truth. ${ }^{118}$

Kant's partiality towards reason is shown in no unclear terms in the abovecited excerpt. He is convinced that the human impetus to be free along with the natural receptivity to truth can only be fulfilled when one embraces what he imagines as the reign of an enlightened rationality. This regime of reason, in the Kantian vision, must be free from the encumbrance of past intellectual or cultural sympathies. Traces or remnants of these sympathies must be seen as impediments to the attainment of emancipation and must hence be overcome. This is Kant's way of picturing the culture of Enlightenment as the great re-set.

What I have endeavored to demonstrate up to this point is a portion of the philosophic conversations which shaped the intellectual tradition called Enlightenment. It can be safely argued, I suppose, that despite Kant's explicit claims against it, the participants themselves of the Enlightenment movement were engaged, to a certain degree, in nonage by virtue of their complicity in the cultivation of the same tradition they were all seeking to foment. This nonage took the form of vigorous exchanges which allowed the current of thought among and between the Dutch, Scottish, English, French, and German Enlightenment proponents flowing freely. If repudiation of nonage is a statement against thinking within a tradition, the foregoing account shows how Kant himself is guilty of self-contradiction which can invalidate his claim. Kant was right in making freedom of thought the leitmotif of the Enlightenment age but the suggestion that such freedom of thought can only be secured via a total abdication of tradition may be untenable even if one measures it against the Enlightenment's norms. Moreover, Kant's presumption that religion is incompatible with the exercise of public reason is likewise arguable given a number of Enlightenment thinkers who maintained their creedal commitments without abandoning their adherence to Enlightenment values. It turns out it is not tutelage nor nonage nor religion that impedes the practice of public reason but rather the failure to 
recognize the plural nature of perspectives and the excessive confidence of thinking for oneself exclusive of self-critique and deliberative discourse.

\section{Conclusion}

The phrase post-Thomistic age is a testament to the plurality of hermeneutic horizons surrounding the relation between faith and reason inside and outside the Catholic philosophic circle and to the possibility as well of reading Aquinas differently. Kant's original prescription to isolate faith from public reason as a requisite of Enlightenment and Habermas' initial acquiescence with such a proposal provides the context for this re-reading. As shown by his philosophic itinerary however, Habermas himself gradually realized such an isolationist attitude toward faith and reason can in fact be counter-productive. It took a Kantian like Habermas himself to clarify why, on the issue of faith and reason, Kant himself should be read differently. Habermas described post-Enlightenment culture as post-metaphysical to suggest not necessarily an anti-metaphysical stance but an occasion to re-think metaphysical thought. In this new intellectual environment, neither a token affirmation nor a rejection of metaphysics is no longer adequate. The practice of Catholic philosophy then in the post-Thomistic age may include transcending metaphysics within metaphysics as in the case of Aquinas just as the exercise of public reason may also involve surpassing tradition within tradition as in the case of Kant. In other words, the translation of discourse proposed by proponents of public reason should be organic and bilateral unlike the prescriptive and one-sided conversion advocated by key liberal thinkers like John Rawls. This kind of reconstructive thinking is what, I suppose, would create the necessary hermeneutic space through which Catholic philosophy can secure itself a hearing in the public sphere. That thinking is by nature bound by tradition is something every practitioner of Catholic philosophy is cognizant of. That it should be confined within a privileged tradition or within a privileged reading of a certain tradition, Thomistic or otherwise, is a temptation that must be overcome. Aquinas himself showed through his philosophic example how this might be carried out and, in the process, demonstrated his own rendition of public 
reason. He incorporated faith in his philosophic discourses convinced of its inherent potential to enrich rational process and worldview formation. In the post-Thomistic age, a practitioner of Catholic philosophy has the responsibility of affirming this natural proclivity of faith. The courage to think and read differently, just as either Aquinas or Kant or any philosopher did for that matter, is instrumental in fulfilling this mandate. 


\section{Notes}

1. Immanuel Kant, What is Enlightenment? www.columbia.edu/acis/ets/CCREAD/ etscc/kant.html.

2. John Paul II, Fides et Ratio www.vatican.va/content/john-paul-ii/en/encyclicals/documents/hf_jp-ii_enc_14091998_fides-et-ratio.html.

3. Alasdair MacIntyre, God, Philosophy, Universities: A Selective History of the Catholic Philosophic Tradition, Rowmam \& Littlefield, 2009, pp. 165-171.

4. Kant, What is Enlightenment? www.columbia.edu/acis/ets/CCREAD/etscc/kant. html.

5. Jean-Pierre Torrel, OP, Saint Thomas Aquinas: The Person and His Work, rev. ed., vol. I, translated by Robert Royal ,The Catholic U of America P, 2005), p.7.

6. Anthony Celano, "The relation of prudence and synderesis to happiness in the medieval commentaries on Aristotle's ethics", The Reception of Aristotle's Ethics, edited by Jon Miller, Cambridge UP, 2002, p.129.

7. Thomas Aquinas, On Being and Essence isidore.co/aquinas/english/ DeEnte\&Essentia.htm

8. Thomas Aquinas, The Principles of Nature isidore.co/aquinas/english/ DePrincNaturae.htm

9. Torrell, OP, pp. 47-50..

10. Eleonore Stump. Aquinas, Routledge, 2003, p. 10. See also John Marenbon, Medieval Philosophy: A Historical and Philosophical Introduction, Routledge, 2007, pp.254-270.

11. Thomas Aquinas, On the Uniqueness of Intellect against Averroists isidore.co/ aquinas/english/DeUnitateIntellectus.htm

12. Thomas Aquinas, On the Eternity of the World isidore.co/aquinas/english/ DeEternitateMundi.htm

13. For an account of the distinctive intellectual features of the Latin Averroists, see Marenbon, pp. 255-256.

14. Alfred Ivry, "Averroes", Routledge History of Philosophy Volume III: Medieval Philosophy, edited by John Marenbon, Routledge, 2004, pp. 49-64.

15. Al-Ghazali, Tahafut Al-Falasifah (Incoherence of the Philosophers), translated by Sabih Ahmad Kamali, Pakistan Philosophical Congress, 1963, pp.4-5.

16. Averroes, Averroes' Tahafut al-Tahafut (The Incoherence of the Incoherence), translated by Simon Van Den Bergh, vols. I and II, EJW Gibb Memorial Trust, 1987, p.361.

17. Ivry, p. 51.

18. In an important article, David Burrell qualifies Aquinas' attitude towards Averroes as more guarded compared to his treatment of Maimonides and 
Avicenna whom he treated more as interlocutors. See David Burrel, "Thomas Aquinas and Islam”, Modern Theology, vol. 2, issue 1, Jan. 2004, pp. 71-89.

19. Thomas Aquinas, Truth, 10.8, isidore.co/aquinas/english/QDdeVer10.htm\#8.

20. Aquinas, Summa Theologica, 1.87 .1 isidore.co/aquinas/english/summa/FP/ FP087.html\#FPQ87A1THEP1.

21. Aquinas, On Being and Essence, 5 isidore.co/aquinas/english/DeEnte\&Essentia. htm.

22. Aquinas, On the Uniqueness of Intellect against the Averroists, 2.59 isidore.co/ aquinas/english/DeUnitateIntellectus.htm\#2.

23. John F. Wippel, "The Parisian Condemnations of 1270 and 1277", A Companion to Philosophy in the Middle Ages, translated by Jorge J.E. Gracia and Timothy B. Noone, Blackwell Publishing Ltd., 2002, pp. 65-66.

24. By the 1270 's, due to the growing influence of Aristotle's natural philosophy, a new round of ecclesiastical censorship once more targeted not just Aristotelian texts but also those treatises with explicit affinity with Aristotelian concepts. Included in the condemned texts were portions of Aquinas' writings. See Edward Grant, God and Reason in the Middle Ages, Cambridge UP, 2001, pp.182-184; see also Fergus Kerr, After Aquinas: Versions of Thomism, Blackwell Publishing, Ltd., 2002, pp.12-14.

25. Maurice De Wulf, "The Teachings of Anti-Scholastic Averroism”, History of Medieval Philosophy maritain.nd.edu/jmc/etext/homp339.htm

26. Aristotle, De Anima Book III classics.mit.edu/Aristotle/soul.3.iii.html

27. Aristotle, De Anima. Book I classics.mit.edu/Aristotle/soul.1.i.html

28. Aristotle, De Anima. Book II classics.mit.edu/Aristotle/soul.2.ii.html

29. Herbert A. Davidson, Alfarabi, Avicenna \& Averroes on the Intellect: Their Cosmologies, Theories of the Active Intellect and Theories of Human Intellect, Oxford UP, 1992, p.46.

30. Davidson, p. 82.

31. Davidson, p. 87

32. Davidson, p. 262

33. Davidson, p. 288.

34. For an account of Siger of Brabant's biography as well as his role in the intellectual debates of the mid- $13^{\text {th }}$ century, refer to Carlos B. Bazan, "Siger of Brabant", A Companion to Philosophy in the Middle Ages, edited by Jorge J.E. Gracia and Timothy B. Noone, Blackwell Publishing, 2002, pp. 632-640.

35. See Stone, MWF. "The Soul's relation to the body: Thomas Aquinas, Siger of Brabant and the Parisian debate on monopsychism", History of the Mind-Body Problem, edited by Tim Crane and Sarah Patterson, Routledge, 2000, pp.42-45.

36. See Sten Ebbesen, Averroism www.muslimphilosophy.com/ip/rep/B012.htm

37. Marenbon, Later Medieval Philosophy (1150 - 1350): An Introduction, Routledge, 1996, p.68. 
38. Aquinas, On the Uniqueness of Intellect against the Averroists isidore.co/aquinas/ english/DeUnitateIntellectus.htm.

39. Aquinas, On the Uniqueness of Intellect against the Averroists 3.84 isidore.co/ aquinas/english/DeUnitateIntellectus.htm\#3

40. Aquinas, 2.59 isidore.co/aquinas/english/DeUnitateIntellectus.htm\#2 .

41. Aquinas, 5.104 isidore.co/aquinas/english/DeUnitateIntellectus.htm\#5

42. Aquinas, 5.124 isidore.co/aquinas/english/DeUnitateIntellectus.htm\#5

43. Aristotle, Physics 8.1 classics.mit.edu/Aristotle/physics.8.viii.html.

44. Plato, Timaeus classics.mit.edu/Plato/timaeus.html

45. See Augustine, The City of God, Vol. 1, Book X1.6 www.gutenberg.org/ files/45304/45304-h/45304-h.htm\#Page_436.

46. See Augustine, Confessions, Book 11 www.gutenberg.org/files/3296/3296h/3296-h.htm\#link2H_4_0011.

47. See Boethius, The Consolation of Philosophy, Book 5.6 www.gutenberg.org/ files/14328/14328-h/14328-h.htm\#Page_229.

48. Richard C. Dales, Medieval Discussions of the Eternity of the World, E.J. Brill, 1990, p. 50.

49. Peter Lombard, The Sentences. Book 2. On Creation, translated by Giulio Silano, Pontifical Institute of Mediaeval Studies, 2008, pp.3-4.

50. Lombard, p. 3; see also Philipp W. Rosemann, Peter Lombard, Oxford UP, 2004, p. 94.

51. Edward Grant, Planet, Stars \& Orbs: The Medieval Cosmos, 1200 - 168, Cambridge UP, 1996, p. 65.

52. See Francis J. Kovach, "The Question of the Eternity of the World in St. Bonaventure and St. Thomas-A Critical Analysis", The Southwestern Journal of Philosophy, vol. 5, no. 2, (Summer, 1974), pp. 141-172.; JBM Wissink, editor, The Eternity of the World in the Thought of Thomas Aquinas and his Contemporaries, E.J. Brill, 1990.

53. Silvia Donati, "Giles of Rome" in Jorge J.E Gracia \& Timothy B. Noone. A Companion to the Philosophy of the Middle Ages, Blackwell Publishing, Inc., 2002, pp. 266-271.

54. Wippel, pp. 65-73.

55. JMMH Thijssen, "1277 Revisited: A New Interpretation of the Doctrinal Investigations of Thomas Aquinas and Giles of Rome”, Vivarium, vol. 35, no. 1, 1997, pp. 72-101.

56. Cited in Walter H. Principe, CSB, "Bishops, Theologians and Philosophers in Conflict at the Universities of Paris and Oxford: The Condemnations of 1270 and 1277", ejournals.bc.edu/index.php/ctsa/article/view/3301; see also Thomas P. J. Bukowski, "J. Pecham, T. Aquinas, et al., on the Eternity of the World." Recherches de théologie ancienne et médiévale, vol. 46, Jan.-Déc. 1979, pp. 216-221; 
Bernardino M. Bonansea, "The Question of An Eternal World in the Teaching of St. Bonaventure”, Franciscan Studies, vol. 34, 1974, pp. 7-33.

57. For a more nuanced appreciation of this matter, see Thomas Bukowski, "Understanding St. Thomas on the Eternity of the World: Help from Giles of Rome?” Recherches de théologie ancienne et médiévale, vol. 58, Jan.-Déc. 1991, pp. 113-125.

58. Jakob Hans Josef Schneider, "The Eternity of the World: Thomas Aquinas and Boethius of Dacia”, Archives D'histoire Doctrinale Et Littéraire Du Moyen Âge, vol. 66, 1999, pp. 121-141.

59. Aquinas, On the Eternity of the World, isidore.co/aquinas/english/ DeEternitateMundi.htm

60. Aquinas, Summa Contra Gentiles 2.35-37 isidore.co/aquinas/english/ ContraGentiles2.htm

61. Aquinas, On the Power of God 3.17 isidore.co/aquinas/english/QDdePotentia. htm\#1:3

62. Aquinas, Summa Theologica 1.45 .1 isidore.co/aquinas/english/summa/FP/ FP045.html\#FPQ45A1THEP1

63. Schneider, p. 128.

64. Aquinas, Summa Contra Gentiles 1.7.1 isidore.co/aquinas/english/ ContraGentiles 1.htm\#7

65. Cited in Carlos B. Bazan, "Boethius of Dacia”, Gracia and Noone, 2002, p. 228.

66. Bertrand Russell, A History of Western Philosophy, George Allen \& Unwin, 1961, p. 461.

67. Alasdair MacIntyre, Whose Justice? Which Rationality? U of Notre Dame P, 1988, p. 350; MacIntyre, Dependent Rational Animals: Why Human Beings Need the Virtues. Carus Publishng, 2002, p. 77.

68. Michael Allan Gillespie, The Theological Origins of Modernity, The U of Chicago P, 2008, p. 262.

69. Sam Harris, A Letter to the Christian Nation, Vintage, 2006, pp. 25-28.

70. Sam Harris, The End of Faith: Religion, Terror and the Future of Reason, W.W. Norton \& Company, 2004, p. 225.

71. Harris, p. 25.

72. Harris, pp. 23-25

73. Augustine, City of God and Christian Doctrine, translated by Philip Schaff Christian Classics Ethereal Library, 1890, p. 72.

74. Augustine, p.79.

75. Victor J. Stenger, The New Atheism: Taking a Stand for Science and Reason, Prometheus Books, 2009, pp. 19-44.

76. LeDrew, p. 15.

77. Thea Hobson, "Richard Dawkins has lost: meet the new new atheists", www. spectator.co.uk/article/richard-dawkins-has-lost-meet-the-new-new-atheists 
78. Terry Eagleton, "Lunging, Flailing, Mispunching", www.lrb.co.uk/ the-paper/v28/n20/terry-eagleton/lunging-flailing-mispunching?referrer=https\%3A\%2F\%2Fwww.google.com\%2F

79. Eagleton, www.lrb.co.uk/the-paper/v28/n20/terry-eagleton/lunging-flailing-mispunching?referrer=https $\% 3 \mathrm{~A} \% 2 \mathrm{~F} \% 2 \mathrm{Fwww}$.google.com $\% 2 \mathrm{~F}$

80. James Wood, “God in the Quad” www.newyorker.com/magazine/2009/08/31/ god-in-the-quad

81. Jurgen Habermas, Religion and Rationality: Essays on Reason, God and Modernity. Polity Press, 2002, p. 152.

82. See Habermas, "Religion in the Public Sphere", European Journal of Philosophy, vol. 14, issue 1, April 2006, pp. 1-25.

83. Habermas, The Theory of Communicative Action, vol. 2, Lifeworld and System: A Critique of Functionalist Reason, Beacon Press, 1987, p. 77.

84. Habermas, p. 87.

85. Habermas, Moral Consciousness and Communicative Action, translated by Christian Lenhardt and Shierry Weber Nicholsen, Polity Press, 2007, p. 93.

86. Habermas, Postmetaphysical Thinking: Philosophical Essays, translated by William Mark Hohengarten, The MIT Press, 1992, p. 51.

87. Habermas, pp. 28-53.

88. See for example, Richard Rorty \& Gianni Vattimo, The Future of Religion, edited by Santiago Zabala. Columbia UP, 2005, pp. 43-54.

89. Gianni Vattimo, After Christianity, Columbia UP, 2002, pp. 103-121.

90. Richard Kearney, Anatheism: Returning to God after God, Columbia UP, 2011, pp. 57-81.

91. Kevin Hart, “Theology without Metaphysics?”, Eric E. Hall \& Harmut von Sass, Groundless Gods: The Theological Prospects of Post-Metaphysical Thought, edited by Wipf \& Stock Publishers, 2014, pp. 41-58.

92. Kevin W. Hector, Theology Without Metaphysics: God, Language and the Spirit of Recognition, Cambridge UP, 2011, pp. 1-46.

93. Jean-Luc Marion, "Thomas Aquinas and Onto-theology", Mystics: Presence and Aporia, edited by Michael Kessler \& Christian Sheppard, The U of Chicago P, 2003, pp.38-74.

94. Habermas, Between Naturalism and Religion: Philosophical Essays, translated by Ciaran Cronin, Polity Press, 2008, p. 130.

95. John F. Wippel, Metaphysical Themes in Thomas Aquinas II, The Catholic U of America P, 2007, pp. 272-289.

96. Martin Heidegger, Identity and Difference, translated by Joan Stambaugh, Harper \& Row, 1969, p. 54.

97. Heidegger, p. 55.

98. Heidegger, p. 59. 
99. Aquinas, Commentary on Metaphysics, isidore.co/aquinas/english/Metaphysics. htm

100. Aquinas, On Being and Essence isidore.co/aquinas/english/DeEnte\&Essentia.htm

101. Aquinas, "Of the simplicity of God", Summa Theologica 1.3 isidore.co/aquinas/ english/summa/FP/FP003.html\#FPQ3OUTP1

102. Aquinas, "That God is not a form of any body", Summa Contra Gentiles 1.27.1 isidore.co/aquinas/english/ContraGentiles1.htm\#27

103. Aquinas, On the Power of God, 3.4 isidore.co/aquinas/english/QDdePotentia. htm\#3:4

104. Aquinas, "That God is to all things the cause of being", Summa Contra Gentiles, 2.15. 6-8 isidore.co/aquinas/english/ContraGentiles2.htm\#15

105. Aquinas, "That God is to all things the cause of being", Summa Contra Gentiles, 2.15.5 isidore.co/aquinas/english/ContraGentiles2.htm\#15

106. Aquinas, "Whether God can be known in this life by natural reason?", Summa Theologica, 1.12.12 isidore.co/aquinas/english/summa/FP/FP012. html\#FPQ12A12THEP1

107. Russell, p. 303.

108. Martin Fitzpatrick et al.,editors, The Enlightenment World, Routledge, 2004, pp. 81-85.

109. Louis Dupre, Enlightenment and the Intellectual Foundations of the Modern Culture, Yale UP, 2004, p. 7.

110. Michel Foucault, The Politics of Truth, translated by Lysa Hochroth \& Catherine Porter, Semiotext(e), 2007, pp. 97-119; see also James Schmidt, editor, What is Enlightenment? Eighteenth-Century Answers and Twentieth-Century Questions, U of California P, 1996, pp. 345-532; Katerina Deligiorgi, Kant and the Culture of Enlightenment, State U of New York P, 2005, pp. 159-185; Fitzpatrick, pp. 571-659.

111. Schmidt, pp. 53-57, 65-77, 78-83, 49-52.

112. Fitzpatrick, pp. 426-441.

113. Fitzpatrick, pp. 421-425.

114. Habermas, The Structural Transformation of the Public Sphere: An Inquiry into a Category of Bourgeois, translated by Thomas Burger, The MIT Press, 1991, pp. 25-26.

115. Moses Mendelssohn, “On the Question: What is Enlightenment?" in Schmidt., pp. 53-57.

116. Johann Karl Wilhelm Mohsen, "What Is to Be Done toward the Enlightenment of the Citizenry?”, pp. 49-52.

117. Friedrich Heinrich Jacobi, "Something Lessing Said: A Commentary on Journeys of the Popes", p.199.

118. Immanuel Kant. Religion within the Boundaries of Mere Reason and Other Writings, translated by Allen Wood \& George di Giovanni, Cambridge UP, 1998, p. 14. 


\section{Works Cited}

\section{Books}

Al-Ghazali. Tahafut Al-Falasifah (Incoherence of the Philosophers). Translated by Sabih Ahmad Kamali, Pakistan Philosophical Congress, 1963.

Augustine. City of God and Christian Doctrine. Translated by Philip Schaff, Christian Classics Ethereal Library, 1890.

Averroes. Averroes' Tahafut al-Tahafut (The Incoherence of the Incoherence). Translated by Simon Van Den Bergh, vols. I and II, EJW Gibb Memorial Trust, 1987.

Bazan, B. Carlos. "Siger of Brabant." A Companion to Philosophy in the Middle Ages, edited by Jorge J.E. Garcia and Timothy B. Noone, Blackwell Publishing, 2002

Celano, Anthony. "The relation of prudence and synderesis to happiness in the medieval commentaries on Aristotle's ethics." The Reception of Aristotle's Ethics, edited by Jon Miller, Cambridge UP, 2002.

Crane, Tim, and Sarah Patterson, editors. History of the Mind-Body Problem. Routledge, 2000.

Dales, Richard C. Medieval Discussions of the Eternity of the World. E.J. Brill, 1990.

Deligiorgi, Katerina. Kant and the Culture of Enlightenment. State U of New York P, 2005.

Donati, Silvia. "Giles of Rome." A Companion to the Philosophy of the Middle Ages, edited by Jorge J.E. Gracia \& Timothy B. Noone, Blackwell Publishing, 2002.

Dupre, Louis. Enlightenment and the Intellectual Foundations of the Modern Culture. Yale UP, 2004.

Fitzpatrick Martin, et al. editors. The Enlightenment World. Routledge, 2004.

Foucault, Michel. The Politics of Truth. Translated by Lysa Hochroth \& Catherine Porter, Semiotext(e), 2007.

Gracia, Jorge J. E., and Timothy B. Noone, editors. A Companion to Philosophy in the Middle Ages. Blackwell Publishing,2002.

Gillespie, Michael Allen. The Theological Origins of Modernity. The U of Chicago P, 2008.

Grant, Edward. Planet, Stars \& Orbs: The Medieval Cosmos, 1200 - 1687. Cambridge UP, 1996.

---. God and Reason in the Middle Ages. Cambridge UP, 2001.

Habermas. Jurgen. The Theory of Communicative Action, Volume 2, Lifeworld and System: A Critique of Functionalist Reason. Beacon Press, 1987.

---. The Structural Transformation of the Public Sphere: An Inquiry into a Category of Bourgeois. Translated by Thomas Burger, The MIT Press, 1991. 
---. Postmetaphysical Thinking: Philosophical Essays. Translated by William Mark Hohengarten, The MIT Press, 1992

---. Religion and Rationality: Essays on Reason, God and Modernity. Polity Press, 2002.

---. Moral Consciousness and Communicative Action. Translated by Christian Lenhardt and Shierry Weber Nicholsen, Polity Press, 2007.

---. Between Naturalism and Religion: Philosophical Essays. Translated by Ciaran Cronin, Polity Press, 2008.

Harris, Sam. The End of Faith: Religion, Terror and the Future of Reason. W.W. Norton, 2004.

---. A Letter to the Christian Nation, Vintage, 2006.

Hall, Eric and Harmut von Sass, Groundless Gods: The Theological Prospects of PostMetaphysical Thought, edited by Wipf \& Stock Publishers, 2014.

Hart, Kevin. "Theology without Metaphysics?”, Eric E. Hall \& Harmut von Sass, Groundless Gods: The Theological Prospects of Post-Metaphysical Thought, edited by Wipf \& Stock Publishers, 2014.

Hector, Kevin. Theology Without Metaphysics: God, Language and the Spirit of Recognition. Cambridge UP, 2011

Heidegger, Martin. Identity and Difference. Translated by Joan Stambaugh, Harper \& Row, 1969.

Ivry, Alfred. "Averroes." Routledge History of Philosophy Volume III: Medieval Philosophy, edited by John Marenbon, Routledge, 2004.

Jacobi, Friedrich Heinrich. "Something Lessing Said: A Commentary on Journeys of the Popes." What is Enlightenment? Eighteenth-Century Answers and TwentiethCentury Questions, edited by James Schmidt, U of California P, 1996.

Kant, Immanuel. Religion within the Boundaries of Mere Reason and Other Writings. Translated by Allen Wood and George di Giovanni, Cambridge UP, 1998.

Kearney, Richard. Anatheism: Returning to God after God. Columbia UP, 2011

Kerr, Fergus. After Aquinas: Versions of Thomism. Blackwell, 2002.

Kessler, Michael and Christian Sheppard, editors. Mystics: Presence and Aporia, The U of Chicago P, 2003

Kretzmann, Norman, et al., editors. The Cambridge History of Later Medieval Philosophy: From the Rediscovery of Aristotle to the Disintegration of Scholasticism, 1100 - 1600. Cambridge UP, 2000.

LeDrew, Stephen. The Evolution of Atheism: The Politics of Modern Movement. Oxford UP, 2016.

Lombard, Peter. The Sentences, Book 2: On Creation. Translated by Giulio Silano, Pontifical Institute of Mediaeval Studies, 2008.

MacIntyre, Alasdair. Whose Justice? Which Rationality? U of Notre Dame P, 1988.

---. Dependent Rational Animals: Why Human Beings Need the Virtues. Carus Publishing, 2002. 
---. God, Philosophy, Universities: A Selective History of the Catholic Philosophic Tradition, Rowmam \& Littlefield, 2009.

Marenbon, John. Later Medieval Philosophy (1150 - 1350): An Introduction. Routledge, 1996.

---. Routledge History of Philosophy, Volume III: Medieval Philosophy. Routledge, 2004.

---. Medieval Philosophy: A Historical and Philosophical Introduction. Routledge, 2007.

Marion, Jean-Luc. "Thomas Aquinas and Onto-theology", Mystics: Presence and Aporia, edited by Michael Kessler \& Christian Sheppard, The U of Chicago P, 2003.

Mendelssohn, Moses. "On the Question: What is Enlightenment?" What is Enlightenment? Eighteenth-Century Answers and Twentieth-Century Questions, edited by James Schmidt, U of California P, 1996.

Miller, Jon, editor. The Reception of Aristotle's Ethics. Cambridge UP, 2002.

Mohsen, Johann Karl Wilhelm. "What Is to Be Done toward the Enlightenment of the Citizenry?" What is Enlightenment? Eighteenth-Century Answers and Twentieth-Century Questions, edited by James Schmidt, U of California P, 1996.

Rorty, Richard and Gianni Vattimo. The Future of Religion, edited by Santiago Zabala, Columbia UP, 2005.

Rosemann, Philipp W. Peter Lombard. Oxford UP, 2004.

Russell, Bertrand. The History of Western Philosophy, George Allen \& Unwin, 1961.

Schmidt, James, editor. What is Enlightenment? Eighteenth-Century Answers and Twentieth-Century Questions. U of California P, 1996.

Stone, MWF. "The Soul's relation to the body: Thomas Aquinas, Siger of Brabant and the Parisian debate on monopsychism." History of the Mind-Body Problem, edited by Tim Crane and Sarah Patterson, Routledge, 2000.

Stenger, Victor J. The New Atheism: Taking a Stand for Science and Reason. Prometheus Books, 2009.

Stump, Eleonore. Aquinas. Routledge, 2003.

Torrell, Jean-Pierre, OP. Saint Thomas Aquinas: The Person and His Work, rev. ed., vol. I, translated by Robert Royal, The Catholic U of America P, 2005.

Wippel, John F. Metaphysical Themes in Thomas Aquinas II. The Catholic U of America P, 2007.

---. "The Parisian Condemnations of 1270 and 1277." A Companion to Philosophy in the Middle Ages, edited by Jorge J.E. Gracia and Timothy B. Noone, Blackwell Publishing, 2002.

Vattimo, Gianni, After Christianity, Columbia UP, 2002.

Wissink, JBM, editor. The Eternity of the World in the Thought of Thomas Aquinas and his Contemporaries. E.J. Brill, 1990. 


\section{Articles}

Bonansea, Bernardino M. "The Question of an Eternal World in the Teaching of St. Bonaventure." Franciscan Studies, vol. 34, 1974, pp. 7-33.

Bukowski, Thomas P. "J. Pecham, T. Aquinas, et al., on the Eternity of the World." Recherches de théologie ancienne et médiévale, vol. 46, Jan.-Déc. 1979, pp. 216-221.

---. Bukowski, Thomas. "Understanding St. Thomas on the Eternity of the World: Help from Giles of Rome?” Recherches de théologie ancienne et médiévale, vol. 58, Jan.-Déc. 1991, pp. 113-125.

Burrel, David. "Thomas Aquinas and Islam.” Modern Theology, vol. 2, issue 1, Jan. 2004, pp. 71-89.

Habermas, Jurgen. "Religion in the Public Sphere." European Journal of Philosophy, vol. 14, issue 1, Apr. 2006.

Kovach, Francis J. "The Question of the Eternity of the World in St. Bonaventure and St. Thomas-A Critical Analysis.” The Southwestern Journal of Philosophy, vol. 5, no. 2, Summer 1974, pp. 141-172.

Schneider, Jakob Hans Josef. "The Eternity of the World: Thomas Aquinas and Boethius of Dacia." Archives D'histoire Doctrinale Et Littéraire Du Moyen Âge, vol. 66, 1999, pp. 121-141.

Thijssen, JMMH. “1277 Revisited: A New Interpretation of the Doctrinal Investigations of Thomas Aquinas and Giles of Rome.” Vivarium, vol. 35, no. 1, 1997, pp. 72-101.

\section{Internet Sources}

Aquinas, Thomas. Commentary on Metaphysics. Translated by John P. Rowan, Chicago, 1961, html-edited by Joseph Kenny, OP, isidore.co/aquinas/english/ Metaphysics.htm.

---. On Being and Essence. Translated 1965, adapted and html-edited by Joseph Kenny, OP, isidore.co/aquinas/english/DeEnte\&Essentia.htm.

---. On the Eternity of the World. Translated by Robert T. Miller, 1991, 1997, reformatted by Joseph Kenny, OP isidore.co/aquinas/english/DeEternitateMundi. htm.

--- On the Power of God. Translated by the English Dominican Fathers, 1952, html-edited by Joseph Kenny, OP isidore.co/aquinas/english/QDdePotentia. htm.

---. On the Uniqueness of the Intellect against the Averroists. isidore.co/aquinas/english/ DeUnitateIntellectus.htm.

---. Summa Contra Gentiles, Book 1, God. Translated by Anton Pegis, 1955-57, html-edited by Joseph Kenny, OP isidore.co/aquinas/english/ContraGentiles1. htm. 
--- Summa Contra Gentiles, Book 2, Creation. Translated by James F. Anderson, 1955-57 html-edited by Joseph Kenny, OP isidore.co/aquinas/english/ ContraGentiles2.htm.

---. Summa Theologica. Translated by the English Dominican Fathers, 1947, digitally adapted by Sandra K. Pery isidore.co/aquinas/english/summa/index.html

---. The Principles of Nature. Translated by R.A. Kocourek, html-edited by Joseph Kenny, OP isidore.co/aquinas/english/DePrincNaturae.htm.

--- Truth. Translated by James V, McGlynn, 1953, html-edited by Joseph Kenny, OP isidore.co/aquinas/english/QDdeVer10.htm.

Aristotle. De Anima, Book I. Translated by J.A. Smith classics.mit.edu/Aristotle/ soul.1.i.html.

---. De Anima, Book II. Translated by J.A. Smith classics.mit.edu/Aristotle/soul.2.ii. html.

---. De Anima, Book III. Translated by J.A. Smith classics.mit.edu/Aristotle/soul.3.iii. html.

---. Physics. Translated by R.P Hardie \& R.K. Gaye classics.mit.edu/Aristotle/ physics.html.

Augustine. Confessions. Book 11. Translated by Edward Bouverie Pusey www.gutenberg.org/files/3296/3296-h/3296-h.htm\#link2H_4_0011.

---. The City of God, Vol.1, Book XI,.6. Translated by Marcus Dods www.gutenberg. org/files/45304/45304-h/45304-h.htm\#Page_436.

Boethius. The Consolation of Philosophy. Books V and VI. Translated by H.R. James www.gutenberg.org/files/14328/14328-h/14328-h.htm.

De Wulf, Maurice. "The Teachings of Anti-Scholastic Averroism." History of Medieval Philosophy. maritain.nd.edu/jmc/etext/homp339.htm.

Eagleton, Terry. "Lunging, Flailing, Mispunching." www.lrb.co.uk/ the-paper/v28/n20/terry-eagleton/lunging-flailing-mispunching? referrer=https\%3A\%2F\%2Fwww.google.com\%2F.

Ebbesen, Sten. Averroism. www.muslimphilosophy.com/ip/rep/B012.htm.

Hobson, Thea. "Richard Dawkins has lost: meet the new new atheists." www.spectator.co.uk/article/richard-dawkins-has-lost-meet-the-new-new-atheists.

John Paul II. Fides et Ratio www.vatican.va/content/john-paul-ii/en/encyclicals/ documents/hf_jp-ii_enc_14091998_fides-et-ratio.html.

Kant, Immanuel. What is Enlightenment? Translated by Mary C. Smith www. columbia.edu/acis/ets/CCREAD/etscc/kant.html.

Plato. Timaeus, Translated by Benjamin Jowett classics.mit.edu/Plato/timaeus.html.

Principe, Walter H., CSB. "Bishops, Theologians and Philosophers in Conflict at the Universities of Paris and Oxford: The Condemnations of 1270 and 1277.” ejournals.bc.edu/index.php/ctsa/article/view/3301.

Wood, James. “God in the Quad.” www.newyorker.com/magazine/2009/08/31/ god-in-the-quad. 